\title{
STRATEGI UNTUK MENINGKATKAN KEMAMPUAN BERPIKIR KRITIS MELALUI PEMECAHAN MASALAH POLYA
}

\author{
Widza Nhurul Desyawati ${ }^{1}$ \\ Program Studi Pendidikan Agama Islam, Fakultas Tarbiyah dan Keguruan \\ UIN Sunan Gunung Djati Bandung \\ Email: nhurul_widza@yahoo.co.id
}

\begin{abstract}
This research is motivated by a phenomenon that occurs in Muhammadiyah 2 Cibiru Vocational School, Bandung, that in school the students 'critical thinking skills are still low, due to the lack of students' desire to ask the teacher and there are still many students who only receive the material taught without studying deeper and sustainably and lack of courage of students to express opinions. The purpose of this study was to find out and analyze the influence of Polya's problem solving strategies on students' critical thinking skills in the subjects of Islamic Education and Character Education. The method used in this study is a correlation method with a quantitative approach. This method is considered capable of revealing and analyzing the phenomena that occur in the present and problems that are factual and express them as they are. Data analysis techniques used are partial analysis of indicators, normality test, simple linear regression analysis, correlation analysis, analysis of determination, and hypothesis analysis (partial t test). From the results of the research conducted, statistical calculations were obtained which showed the reality of the influence of the Polya problem solving strategy on students' critical thinking skills of 0.976, the values being in the interval $0.80-1.00$. Then the degree of influence of variable $\mathrm{X}$ on variable $\mathrm{Y}$ is $78 \%$ while $22 \%$ is determined or influenced by other factors that can affect students' critical thinking abilities.
\end{abstract}

Keywords:

Polya's problem solving strategy, Critical Thinking

\begin{abstract}
Abstrak : Penelitian ini dilatarbelakangi oleh fenomena yang terjadi di SMK Muhammadiyah 2 Cibiru Kota Bandung bahwa di sekolah tersebut kemampuan berpikir kritis siswa masih rendah, dikarenakan kurangnya keinginan siswa untuk bertanya kepada guru kemudian masih banyak siswa yang hanya menerima materi yang diajarkan tanpa menelaah lebih dalam dan berkelanjutan serta kurangnya keberanian siswa untuk mengeluarkan pendapat. Tujuan penelitian ini adalah untuk mengetahui dan menganalisa pengaruh strategi pemecahan masalah Polya terhadap kemampuan berpikir kritis siswa pada mata pelajaran Pendididkan Agama Islam dan Budi Pekerti. Metode yang digunakan dalam penelitian ini adalah metode korelasi dengan pendekatan kuantitatif. Metode ini dianggap mampu mengungkap dan menganalisis fenomena-fenomena yang terjadi pada masa sekarang dan masalah-masalah yang bersifat fakta dan mengungkapkannya secara apa adanya. Teknik analisis data yang digunakan adalah analisis parsial perindikator, uji normalitas, analisis regresi linier sederhana, analisis korelasi, analisis determinasi, dan analisis hipotesis (uji t parsial). Dari hasil penelitian yang dilakukan, diperoleh perhitungan statistik yang menunjukan realitas pengaruh strategi pemecahan masalah Polya terhadap kemampuan berpikir kritis siswa sebesar 0,976, nilai tersebut berada pada interval 0,80-1,00. Kemudian derajat pengaruh dari variabel X terhadap variabel Y sebesar $78 \%$ sedangkan $22 \%$ ditentukan atau dipengaruhi oleh faktor lain yang dapat mempengaruhi kemampuan berpikir kritis siswa.
\end{abstract}

Kata kunci:

Strategi pemecahan masalah Polya, Berpikir Kritis 


\section{PENDAHULUAN}

Pendidikan Agama Islam merupakan mata pelajaran yang diajarakan di sekolah, salah satu tujuan dari pendidikan agama Islam yaitu untuk menanamkan ajaran-ajaran Islam dan tatanan nilai hidup dan kehidupan pada siswa berdasarkan ajarannya itu sendiri. Selain itu, tujuan pendidikan agama Islam juga sebagai upaya untuk penyampaian ilmu yang tidak hanya dipahami dan dihayati tetapi untuk diamalkan dalam kehidupan sehari-hari baik untuk dirinya sendiri ataupun kehidupan di masyarakat. Pendidikan agama Islam memiliki peran penting dalam kehidupan. Melalui pendidikan siswa diharapkan dapat mengembangkan atau meningkatkan potensinya berupa kemampuan, keterampilan, keahlian dan pengetahuannya. Keberhasilan suatu pendidikan dapat dilihat dari kemampuan belajar siswa sehingga pengetahuan yang didapat merupakan hasil belajar yang dikuasainya.Adapun salah satu tujuan dari pendidikan agama Islam yaitu siswa diharapkan mampu memahami, mengambil manfaat dan menerapkannya dalam kehidupan sehari-hari (Majid, 2014: 42).

Berdasarkan hasil studi pendahuluan yang dilakukan dengan guru mata pelajaran Pendidikan Agama Islam dan Budi Pekerti di SMK Muhammadiyah 2 Cibiru Kota Bandung diperoleh informasi mengenai rendahnya kemampuan berpikir kritis siswa. Hal tersebut dikarenakan kurangnya keinginan siswa untuk bertanya kepada guru, ketika guru memberikan waktu untuk bertanya siswa hanya diam saja, kemudian masih banyak siswa yang hanya menerima materi yang diajarkan tanpa menelaah lebih dalam dan berkelanjutan, kurangnya keberanian siswa untuk mengeluarkan pendapat, juga siswa hanya menghafal materi tanpa menerapkan materi tersebut dalam kehidupan sehari-hari.

Berpikir kritis merupakan kemampuan untuk mengatakan sesuatu berdasarkan alasan yang logis, memungkinkan siswa untuk menemukan kebenaran suatu infromasi yang ada disekitar mereka, tujuannya untuk mengarahkan agar siswa mampu memahami permasalah tersebut agar dicari solusinya dan dijadikan sebagai pemahaman untuk kehidupannya (Johnson, 2007: 185). Menurut Ennis (Zubaidah, 2015: 203) terdapat beberapa indikator berpikir kritis yang terdiri dari 5 sub indikator yaitu:

1. Memberikan penjelasan sederhana (Elementary clarification), meliputi:

a. Memfokuskan pertanyaan,

b. menganalisis argumen,

c. bertanya dan menjawab pertanyaan yang membutuhkan penjelasan atau tantangan.

2. Membangun keterampilan dasar (Basic support), meliputi:

a. Mempertimbangkan kredibilitas sumber dan melakukan pertimbangan observasi.

3. Penarikan kesimpulan (Inference), meliputi:

a. Menyusun dan mempertimbangkan deduksi

b. Menyusun keputusan dan mempertimbangkan hasilnya

4. Memberikan penjelasan lebih lanjut (Advanced clarification), meliputi: 
a. Mengidentifikasi istilah dan mempertimbangkan definisi, dan mengidentifikasi asumsi.

5. Mengatur strategi dan taktik (Srategies and tactics), meliputi:

a. Menentukan suatu tindakan dan berinteraksi dengan orang lain

Maka dari itu berpikir kritis merupakan kegiatan seseorang dalam berpikir yang dapat dikembangkan oleh setiap orang melalui beberapa indikator ketercapaian. Menyadari pentingnya mengembangkan kemampuan berpikir kritis siswa, maka mutlak diperlukan adanya pembelajaran yang lebih banyak melibatkan siswa secara aktif dalam proses pembelajaran itu sendiri (Johnson, 2007: 189).

Menindaklanjuti hasil studi pendahuluan diatas berarti kemampuan siswa dalam berpikir kritis perlu ditingkatkan karena berpikir kritis sejalan dengan meningkatkan mutu pendidikan melalui proses pembelajaran yang sesuai dengan tuntutan tujuan atau hasil belajar. Berpikir kritis juga akan tercapai dengan adanya kebiasaan, adanya pola pikir siswa untuk berikir kritis. Maka dari itu, sangat penting bagi seorang pembaca dan penulis seperti seorang siswa (bahkan mahasiswa) karena berpikir kritis merupakan salah satu cara untuk mengambil keputusan dalam kehidupan. Dan berpikir kritis juga akan terjadi paa seseorang, ketika seorang siswa meningkatkan kemampuan berpikir kritis maka akan meningkatkan kemampuannya dalam memecahkan permasalahan baik itu dalam pembelajaran ataupun dalam kehidupannya. Berdasarkan hal tersebut diatas maka peneliti menerapkan strategi pemecahan masalah Polya. Tujuannya adalah untuk mengembangkan kemampuan berpikir kritis siswa.

Startegi pemecahan masalah Menurut Polya (1973) merupakan suatu cara belajar yang dianggap sangat efisien dalam usaha untuk mencapai tujuan pengajaran. Proses belajar melalui pemecahan masalah bertolak dari pandangan bahwa siswa sebagai subjek dan objek dalam belajar yang mempunyai kemampuan untuk memecahkan masalah pada dasarnya merupakan tujuan pendidikan, siswa dituntut untuk menjawab pertanyaan-pertanyaan atau memecahkan masalah mereka sehingga siswa termotivasi untuk belajar keras. Ada empat langkah di dalam memecahkan suatu masalah yaitu:

1. See (Understanding the problem) merupakan suatu pemahaman pada masalah yangkegiatannya berupa Identifikasi permasalahan.

2. Plan (Devising Plan), yaitu membimbing untuk mengembangkan cara berpikir agar dapat menganalisis masalah.

3. Do (Carrying out the plan) malaksanakan perencanaan, dengan menyelesaikan permasalahan dengan cara memperkirakan jawaban yang pas untuk memecahkan masalah yang dihadapi.

4. Check (Looking back) yaitu memberikan bimbingan untuk mengecek kembali jawaban yang dibuat. 
Dari beberapa langkah tersebut terlihat sudah menjadi pekerjaan sehari-hari dalam penyelesaian masalah sehingga Polya layak disebut bapak "problem solving" (Amir, 2016: 116).

\section{Gambar Diagram Pemecahan Masalah Polya}

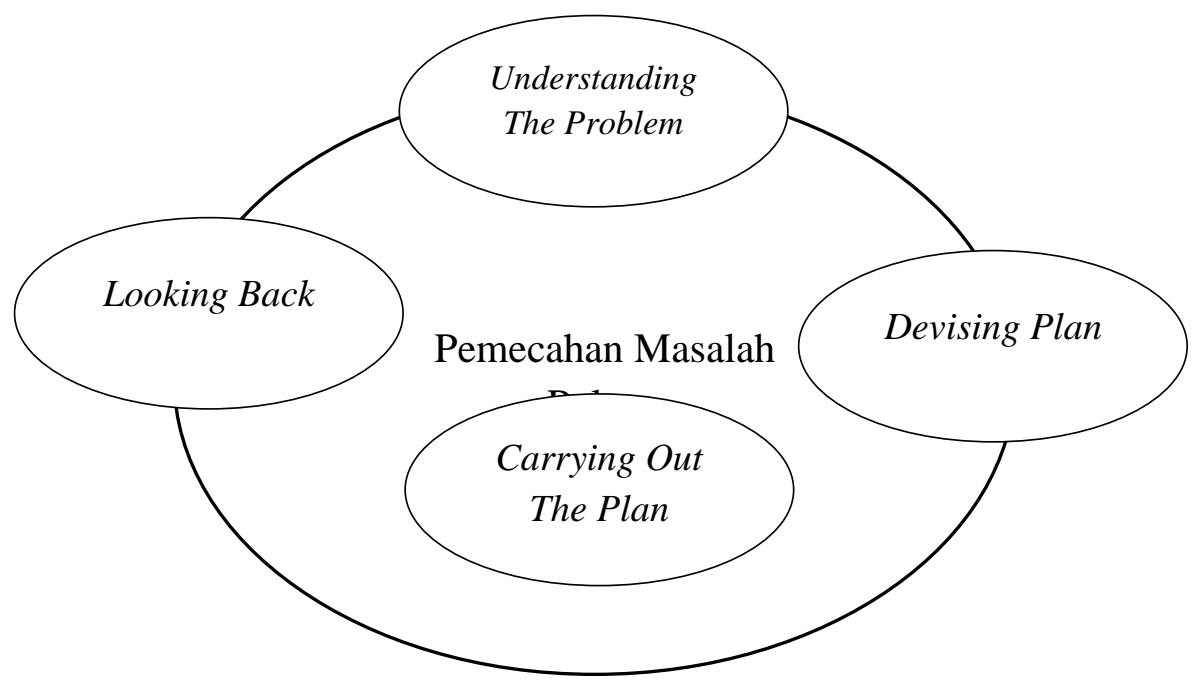

Jadi, strategi pemecahan masalah Polya merupakan suatu strategi yang dapat digunakan untuk mencapai tujuan pendidikan agama islam, namun kecocokan strategi tersebut dapat dilihat ketika adanya pengaruh dari strategi terhadap kemmapuan berpikir kritis siswa.

Hipotesis dari penelitian ini yaitu adanya pengaruh yang positif dan signifikan antara strategi pemecahan Polya terhadap kemampuan berpikir kritis siswa pada mata pelajaran Pendidikan Agama Islam dikelas X di SMK Muhammadiyah 2 Cibiru Kota Bandung.

Kemudian ditemukan beberapa tulisan yang berkaitan dengan penelitian ini yaitu salah satunya penelitian yang dilakukan oleh Ifanali dari hasil penelitian tersebut menunjukkan bahwa pembelajaran menggunakan langkah Polya dapat meningkatkan kemampuan pemecahan masalah siswa dalam menyelesaikan soal cerita pecahan di kelas VII SMP Negeri 13 Palu dengan empat langkah Polya, yaitu: memahami masalah, menyusun rencana, melaksanakan rencana, dan mengecek kembali jawaban yang diperoleh.

Berdasarkan uraian di atas, maka tujuan penelitian ini adalah untuk mengetahui dan menganalisa pengaruh strategi pemecahan masalah Polya terhadap kemampuan berpikir kritis siswa pada mata pelajaran Pendididkan Agama Islam dan Budi Pekerti pada Siswa kelas X Administrasi Perkantoran di SMK Muhammadiyah 2 Cibiru Kota Bandung. 


\section{METODOLOGI}

Penelitian ini menggunakan pendekatan kuantitatif dengan metode korelasi. Menuruut (Sugiyono, 2015: 6) metode korelasi yaitu metode untuk memprediksi skor dan menjelaskan hubungan atau pengaruh diantara variabel-variabel, metode ini digunakan dengan alasan karena masalah yang diteliti merupakan kasus yang terjadi pada masa sekarang atau masih berlangsung serta masalah yang diteliti merupakan permasalahan yang hendak dipecahkan serta dapat diungkapkan secara apa adanya.

Jenis data yang digunakan pada penelitian ini adalah data kuantitatif. Adapun sumber data ini diperoleh dari populasi yang berjumlah 133 dari polpulasi tersebut diambil sampel secara simple random sampling yaitu secara acak tanpa memperhatikan kesetaraan yang ada dalam populasi tersebut. Adapun pengambilan sampel menurut (Arikunto, 2010: 134) yaitu apabila kurang dari 100 maka diambil semua dari populasi tapi apabila lebih dari 100 maka dapat diambil 10\%-25\%. Karena jumlah sampel lebih dari 100 maka dapat diambil 10\%- 25\% adapun peneliti mengambil $25 \%$ dari populasi yaitu $133 \times 25 \%=33,25$ dibulatkan menjadi 33. Adapun Penelitian ini dilakukan di SMK Muhammadiyah 2 Cibiru Kota Bandung. Yang dilakukan pada bulan maret 2018 semester genap.

Salah satu kegiatan perencanaan penelitian adalah merumuskan teknik dan alat pengumpulan data sesuai dengan masalah yang diteliti. Untuk itu pada penelitian ini menggunakan teknik pengumpulan data yaitu pertama, angket yang berjumlah 20 pernyataan yang disertai dengan empat opsi jawaban dengan menggunakan skala pengukuran yaitu skala Likert dengan nilai $1-5$. Nilai yang dimaksud adalah skor atas jawaban responden. Kedua, tes dalam bentuk tulisan yang terdiri dari 12 soal essay sesuai dengan indikator keterampilan berpikir kritis dengan menggunakan skala rubrik penilaian berpikir kritis yang diadaptasi dari Ennis dan Finken (Zubaidah, 2015: 210) dengan rentangan skor 0-5. Ketiga, wawancara yang dilakukan untuk mendapatkan data awal dari respondents juga informasi berupa latar belakang sekolah, letak geografis, jumlah guru/ karyawan, keadaan siswa dan sarana prasarana di SMK Muhammadiyah 2 Cibiru Kota Bandung.

Setelah dilakukan pengumpulan data, selanjutnya dilakukan analisis data. Analisis yang digunakan adalah analisis kuantitatif yaitu analisis untuk menguji hipotesis dengan menggunakan analisis parsial per idnikator, uji normalitas, analisis regresi sederhana, analisis korelasi pearson product moment, uji signifikasi Uji t (Parsial) dan analisis koefesien determinasi. Dengan rumus-rumus sebagai berikut:

a. Analisis parsial perindikator, analsis ini dimaksudkan untuk mencari ratarata skor setiap indikator dari masing-masing variabel. Dengan rumus: $\mathrm{M}=$ $\frac{\sum \mathrm{X}}{\mathrm{n}}$ dan $\mathrm{M}=\frac{\sum \mathrm{Y}}{\mathrm{n}}$. Setelah diketahui rata-rata, kemudian dilakukan identifikasi yang mengacu pada standar penafsiran sebagai berikut : 


\section{Tabel Kualifikasi Variabel X dan Y}

\begin{tabular}{|c|c|}
\hline $0,5-1,5$ & Sangat Rendah \\
\hline $1,6-2,5$ & Rendah \\
\hline $2,6-3,5$ & Sedang \\
\hline $3,6-4,5$ & Tinggi \\
\hline $4,6-5,5$ & Sangat Tinggi \\
\hline
\end{tabular}

(Arikunto, $2010: 255$ )

b. Uji Normalitas, dilakukan untuk menentukan apakah sekumpulan data berdistribusi normal atau tidak.

Dengan ketentuan:

$\mathrm{H}_{0}$ ditolak jika $x^{2}{ }_{\text {hitung }}>x_{\text {tabel }}^{2}$

$\mathrm{H}_{0}$ diterima jika $x^{2}{ }_{\text {hitung }}<x^{2}$ tabel

c. Analisis Regresi Sederhana, digunakan pada penelitian ini untuk mengetahui pengaruh startegi pemecahan masalah Polya terhadap kemampuan berpikir kritis siswa dengan menguji linieritas data dari dua variabel. Dengan rumus: $Y=a+b X$ (Kariadinata, 2012: 324).

Dengan ketentuan:

$$
\begin{gathered}
a=\frac{\left(\sum \mathrm{Y}\right)\left(\sum \mathrm{X}^{2}\right)-\left(\sum \mathrm{X}\right) \cdot\left(\sum \mathrm{X} . \mathrm{Y}\right)}{\mathrm{n} \cdot \sum \mathrm{X}^{2}-\left(\sum \mathrm{X}\right)^{2}} \\
\mathrm{~b}=\frac{\mathrm{n} \cdot \sum \mathrm{XY}-\left(\sum \mathrm{X}\right) \cdot\left(\sum \mathrm{Y}\right)}{\mathrm{n} \cdot \sum \mathrm{X}^{2}-\left(\sum \mathrm{X}\right)^{2}}
\end{gathered}
$$

d. Analisis Korelasi merupakan teknik analisis statistik yang digunakan untuk menguji ada atau tidaknya hubungan serta arah hubungan dua variabel. Menghitung korelasi dengan rumus korelasi product moment. Rumus yang digunakan sebagai berikut:

$\mathrm{r}_{\mathrm{xy}}=\frac{n \cdot \sum X \cdot Y-\left(\sum X\right)\left(\Sigma^{\prime}\right)}{\sqrt{\left\{n \cdot \sum X^{2}-\left(\sum X\right)^{2}\right\} \cdot\left\{n \cdot \sum^{2}-\left(\sum Y\right)^{2}\right\}}} \quad$ (Kariadinata, 2012: 329)

Tabel Interpretasi Koefesien Korelasi

\begin{tabular}{|c|c|}
\hline $0,00-0,20$ & Sangat Rendah (tidak berkorelasi) \\
\hline $0,20-0,40$ & Korelasi Rendah \\
\hline $0,40-0,60$ & Korelasi Sedang \\
\hline $0,60-0,80$ & Korelasi Tinggi \\
\hline $0,80-1,00$ & Korelasi Sangat Tinggi \\
\hline
\end{tabular}

(Sugiyono, 2015: 184)

e. Analisis Uji Hipotesis (Uji t), yaitu untuk melakukan pengujian terhadap hipotesis yang diajukan, dengan rumus:

$$
\mathrm{t}_{\text {hitung }}=\frac{r \sqrt{n-2}}{\sqrt{1-r^{2}}}(\text { Sugiyono, 2015: 184) }
$$

Dengan ketentuan sebagai berikut : 
Hipotesis diterima jika $t_{\text {hitung }}>t_{\text {tabel }}$ atau

Hipotesis ditolak jika $t_{\text {hitung }}<t_{\text {tabel}}$.

f. Analisis Koefesien Determinasi, untuk menunjukan atau mengetahui seberapa besar adanya pengaruh variabel $\mathrm{X}$ yaitu strategi pemecahan masalah Polya terhadap varaibel Y yaitu kemampuan berpikir kritis siswa melalui hubungan linear. Dengan rumus yaitu:

$$
\begin{aligned}
& \mathrm{K}=\sqrt{1-\mathrm{r}^{2}} \text { (Menghitung ketiadaan korelasi) } \\
& \mathrm{E}=100(1-\mathrm{K}) \text { (Menghitung besar kecilnya pengaruh variabel } \mathrm{X} \\
& \text { terhadap } \mathrm{Y} \text { ) }
\end{aligned}
$$

\section{HASIL KAJIAN DAN PEMBAHASAN}

Hasil analisis penelitian ini menyatakan bahwa strategi pemecahan masalah Polya berpengaruh terhadap kemampuan berpikir kritis siswa pada mata pelajaran Pendidikan Agama Islam dan Budi Pekerti. Berdasarkan perhitungan keseluruhan untuk item-item pernyataan yang diberikan kepada siswa terhadap strategi pemecahan masalah Polya apabila mengacu kepada standar penafsiran penilaian termasuk kategori sedang karena berada pada daerah interval 2,6 - 3,5 yaitu terlaksana dengan ketercapaian nilai rata-rata 3,5. Nilai tersebut dikatakan sedang karena berdasarkan analisis angket yang diberikan ada beberapa dari langkah-langkah yang dibuatkan kedalam item angket yang belum tercapai. Misalnya, pada langkah yang pertama yaitu see (understanding the problem) item no 1 masih ada 1 siswa yang memilih jawaban e yaitu tidak pernah memahami masalah pada mata pelajaran pendidikan agama Islam, kemudian pada item no 15 ada 2 siswa yang tidak pernah melakukan langkah yang ke 3 yaitu Do (Carrying out the plan), apabila dijelaskan satu persatu hampir semua item yang diberikan kepada 33 orang siswa masih ada siswa yang tidak pernah melakukan salah satu dari langkah strategi pemecahan masalah Polya tersebut, maka dari itu dari hasil analisis perindikator variabel $\mathrm{X}$ dikategorikan sedang.

Begitupun dengan item-item pernyataan yang diberikan kepada mengenai berpikir kritis masih ada indikator yang tidak dilakukan oleh siswa. Misalnya, pada indikator ke 2 yaitu membangun keterampilan dasar yaitu soal tes essay no 4 hanya ada 1 siswa yang menjawab dengan skor 5 siswa tersebut menjawab dengan benar, spesifik, tata bahasanya baik dan alur bepikirnya jelas. Dengan begitu kemampuan berpikir kritis siswa tersebut dikategorikan dengan ketercapaian sedang.

Kemudian setelah dilakukan analisis parsial perindikator kedua variabel dihitung uji normalitas. Dari perhitungan tersebut kedua data berdistribusi normal dengan hasil yang diperoleh nilai $x^{2}$ hitung sebesar 1,87 dan nilai $x^{2}$ tabel sebesar 11,3 dengan taraf signifikasi $1 \%$ atau 0,01 . Dengan demikian terbukti bahwa nilai $x^{2}$ hitung lebih kecil dari

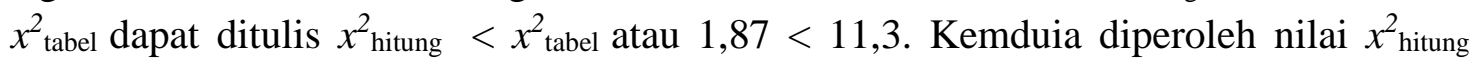
sebesar 9,61 dan nilai $x^{2}$ tabel sebesar 11,3 dengan taraf signifikasi $1 \%$ atau 0,01 . Dengan demikian terbukti bahwa nilai $x^{2}$ hitung lebh kecil dari $x^{2}$ tabel $=11,3$ dapat ditulis $x^{2}$ hitung < $x^{2}$ tabel atau 9,61<11,3 maka Ho diterima. Setelah kedua variabel berdistribusi normal 
selanjutnya menghitung linieritas regresi yaitu berdasarkan perhitungan diperoleh data

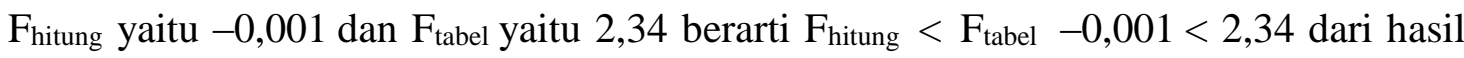
tersebut terbukti bahwa $\mathrm{F}_{\text {hitung }}$ lebih besar dari $\mathrm{F}_{\text {tabel }}$ dengan demikian hubungan variabel $\mathrm{X}$ dan Variabel Y beregresi linier.

Setelah kedua data berdistribusi normal dan beregresi linier kemudian dilanjutkan menghitung analisis korelasi. Berdasarkan hasil analisis korelasi Pearson Product Moment dengan perhitungan:

$$
\begin{aligned}
& \mathrm{r}_{\mathrm{XY}}=\frac{\mathrm{n} \cdot \Sigma \mathrm{X} \cdot \mathrm{Y}-\left(\sum \mathrm{X}\right)\left(\sum \mathrm{Y}\right)}{\sqrt{\left\{\mathrm{n} \cdot \mathrm{X}^{2}-\left(\sum \mathrm{X}\right)^{2}\right\} \cdot\left\{\mathrm{n} \cdot \Sigma \mathrm{Y}^{2}-\left(\sum \mathrm{Y}\right)^{2}\right\}}} \\
& =\frac{33 \cdot(74.280)-(2.318)(1.038)}{\sqrt{\left\{33(163.910)-(2318)^{2}\right\} \cdot\left\{33(34.458)-(1038)^{2}\right\}}} \\
& =\frac{2.451 .240-2.406 .084}{\sqrt{(5.409 .030-5.373 \cdot 124) \cdot(1.137 .114-1.077 .444)}} \\
& =\frac{45.156}{\sqrt{(35.906) \cdot(59.670)}} \\
& =\frac{45.156}{\sqrt{2.142 .511 .020}} \\
& =\frac{45.156}{46.287,26628} \\
& =0,9755 \\
& =0,976
\end{aligned}
$$

\begin{tabular}{|c|c|c|c|}
\hline \multicolumn{4}{|c|}{ Correlations } \\
\hline & & $\begin{array}{c}\text { Strategi } \\
\text { Pemacahan } \\
\text { Masalah Polya }\end{array}$ & Berpikir Kritis \\
\hline \multirow{4}{*}{$\begin{array}{l}\text { Strategi } \\
\text { Pemacahan } \\
\text { Masalah } \\
\text { Polya }\end{array}$} & Pearson & 1 & $.976^{* *}$ \\
\hline & Correlation & & \\
\hline & Sig. (2-tailed) & & .000 \\
\hline & $\mathrm{N}$ & 33 & 33 \\
\hline \multirow{4}{*}{$\begin{array}{l}\text { Berpikir } \\
\text { Kritis }\end{array}$} & Pearson & $.976^{* *}$ & 1 \\
\hline & Correlation & & \\
\hline & Sig. (2-tailed) & .000 & \\
\hline & $\mathrm{N}$ & 33 & 33 \\
\hline
\end{tabular}

Tabel Hasil Analisis Korelasi Product Pearson Moment

Sumber : Output SPSS Versi 25

Dengan diperolehnya nilai korelasi atau $r$ sebesar 0,976 menunjukan terjadinya korelasi yang sangat tinggi. Nilai 0,976 berada di antara $(0,80-1,00)$ yang menunjukan 
adanya hubungan antara strategi pemecahan masalah Polya terhadap kemampuan berpikir kritis siswa karena nilai koefisiennya sangat tinggi. Jadi strategi pemecahan masalah Polya mempunyai hubungan dengan kemampuan berpikir kritis siswa. Nilai $r$ yang semakin mendekati 1 maka variabel independen yang ada dapat memberikan hampir semua informasi yang dibutuhkan untuk memprediksi variabel dependen, dan begitu juga sebaliknya.

Kemudian dilihat dari analisis Uji t dengan uji statistik dapat dirumuskan sebagai berikut:

$$
\begin{aligned}
& \mathrm{t}_{\text {hitung }}=\frac{r \sqrt{\mathrm{n}-2}}{\sqrt{1-r^{2}}} \\
& =\frac{0,976 \sqrt{33-2}}{\sqrt{1-0,976^{2}}} \\
& =\frac{0,976 \sqrt{31}}{\sqrt{1-0,952}} \\
& =\frac{0,976 \cdot 5,568}{0,556} \\
& =\frac{5,43169}{0,2197} \\
& =24,72
\end{aligned}
$$

\begin{tabular}{|c|c|c|c|c|c|c|}
\hline \multicolumn{7}{|c|}{ Coefficients $^{\mathrm{a}}$} \\
\hline \multirow{2}{*}{\multicolumn{2}{|c|}{ Model }} & \multicolumn{2}{|c|}{$\begin{array}{c}\text { Unstandardized } \\
\text { Coefficients }\end{array}$} & \multirow{2}{*}{$\begin{array}{c}\text { Standardized } \\
\text { Coefficients } \\
\text { Beta }\end{array}$} & \multirow[b]{2}{*}{$\mathrm{T}$} & \multirow{3}{*}{$\begin{array}{l}\text { Sig. } \\
.000\end{array}$} \\
\hline & & B & $\begin{array}{l}\text { Std. } \\
\text { Error }\end{array}$ & & & \\
\hline 1 & (Constant) & $\begin{array}{r}- \\
56.884\end{array}$ & 3.465 & & -16.350 & \\
\hline
\end{tabular}

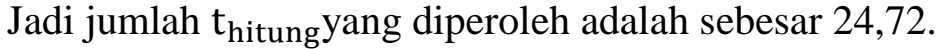

$$
\begin{aligned}
t_{\text {tabel }} & =n-2 \\
& =33-2=31 \text { sehingga diperoleh } \\
t_{\text {tabel }} & =1,69552 \text { atau } 1,69
\end{aligned}
$$

Tabel Hasil Analisis Uji Hipotesis (Uji t) 


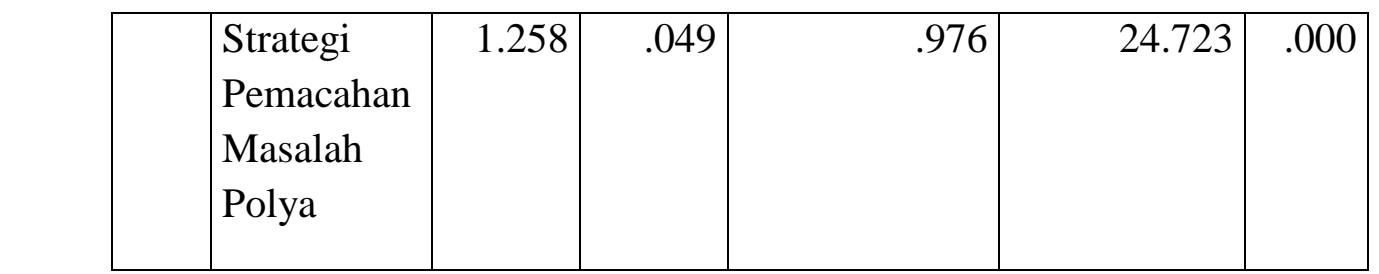

Sumber: Output SPSS Versi 25

Dari perhitungan tersebut menunjukkan $t_{\text {hitung }}>t_{\text {tabel }} 24,72>1,69$ itu artinya hipotesis diterima. Ha (Ada pengaruh yang positif dan signifikan antara strategi pemecahan Polya terhadap kemampuan berpikir kritis siswa pada mata pelajaran Pendidikan Agama Islam dan Budi Pekerti) diterima. Berarti adanya pengaruh yang positif dan signifikan antara strategi pemecahan Polya terhadap kemampuan berpikir kritis siswa pada mata pelajaran Pendidikan Agama Islam dan Budi Pekerti.

Selanjutnya untuk mengetahui seberapa besar kontribusi variabel independen (strategi pemecahan masalah Polya) terhadap variabel dependen (kemampuan berpikir kritis) digunakan analisis koefesien determinasi, dengan tahapan sebagai berikut :

1) Menghitung ketiadaan korelasi dengan rumus :

$$
\begin{aligned}
\mathrm{K} & =\sqrt{1-\mathrm{r}^{2}} \\
& =\sqrt{1-0,976}^{2} \\
& =\sqrt{1-0,95} \\
& =\sqrt{0,05} \\
& =0,22 \\
& =0,22 \times 100=22 \%
\end{aligned}
$$

2) Menghitung besar kecilnya pengaruh variabel $X$ terhadap variabel $Y$ dengan rumus :

$$
\begin{aligned}
\mathrm{E} & =100(1-\mathrm{K}) \\
& =100(1-0,22) \\
& =100(0,78) \\
& =78 \\
& =78 \%
\end{aligned}
$$

Berdasarkan hasil analisis koefisien determinasi diperoleh pengaruh sebesar $78 \%$, itu berarti kemampuan berpikir kritis ditentukan atau dipengaruhi oleh strategi pemecahan masalah Polya melalui hubungan linier sedangkan 22\% ditentukan atau dipengaruhi oleh faktor lain yang tidak dapat mempengaruhi kemampuan berpikir kritis siswa dan tidak disebutkan oleh peneliti

\section{SIMPULAN}

Berdasarkan hasil penelitian menunjukan bahwa strategi pemecahan masalah Polya berpengaruh terhadap kemampuan berpikir kritis siswa pada mata pelajaran Pendidikan Agama Islam dan Budi Pekerti dari sebesar 0,976. Nilai tersebut berada pada 
interval 0,80 - 1,00 yang berarti hubungan antara strategi pemecahan masalah Polya terhadap kemampuan berpikir kritis siswa sangat tinggi. Selanjutnya besarnya pengaruh strategi pemecahan masalah Polya terhadap kemampuan berpikir kritis siswa berdasarkan hasil analisis koefisien determinasi diperoleh pengaruh sebesar $78 \%$, itu berarti kemampuan berpikir kritis ditentukan atau dipengaruhi oleh strategi pemecahan masalah Polya melalui hubungan linier sedangkan 22\% ditentukan atau dipengaruhi oleh faktor lain yang tidak dapat mempengaruhi kemampuan berpikir kritis siswa dan tidak disebutkan oleh peneliti. Kemudian dilihat dari analisis Uji t diperoleh hasil $t_{\text {hitung }}$ sebesar 24,72 kemudian diperoleh $t_{\text {tabel }}$ sebesar 1,69. Hal ini menunjukkan $t_{\text {hitung }}>$ $\mathrm{t}_{\text {tabel }} 24,72>1,69$. Artinya hipotesis terima, maka strategi pemecahan masalah Polya berpengaruh signifikan terhadap kemampuan berpikir kritis siswa pada mata pelajaran Pendidikan Agama Islam dan Budi Pekerti kelas X Administrasi Perkantoran di SMK Muhammadiyah 2 Cibiru Kota Bandung.

\section{SARAN}

Dari hasil analisis variabel $\mathrm{X}$ yang telah dilakukan ternyata strategi pemecahan masalah Polya membantu siswa dalam hal menemukan jawaban atas masalah yang dihadapinya dengan kategori sedang, yaitu siswa dapat bertanya, mengeluarkan pendapat, maka dari itu siswa harus bisa memberanikan diri untuk bertanya, berpendapat agar mampu melatih berpikir kritis dan menjadikan pembelajaran yang dilakukan disekolah tersebut ke dalam kehidupan sehari-hari. Maka pemilihan strategi pembelajaran sangat penting dalam kegiatan belajar mengajar.

Kemudian dari hasil analisis variabel Y ternyata kemampuan berpikir kritis siswa termasuk kategori sedang, maka menuntut guru untuk memperhatikan hal-hal yang berkaitan dengan apa saja yang berpengaruh kepada bagaimana siswa berpendapat, bertanya dan menjawab pertanyaan agar mampu mendapat hasil yang lebih baik. Salah satunya adalah strategi pemeblajaran, agar apapun yang disampaikan guru dan diterima siswa akan tersampaikan dengan baik.

Dari penelitian yang telah dilakukan saran untuk peneliti selanjutnya yaitu sebelum melakukan penelitian persiapkan terlebih dahulu apa saja yang dibutuhkan dalam penelitian agar tersedia waktu lebih banyak dan mendapatkan hasil yang lebih bermanfaat bagi peneliti selanjutnya.

\section{DAFTAR PUSTAKA}

Amir, Z. (2016). Psikologi Pembelajaran Matematika. Yogyakarta: Aswaja Pressindo. Arikunto, S. (2010). Prosedur Penelitian. Jakarta: Rineka Cipta.

Ifanali. (2014). Penerapan Langkah-langkah Polya untuk Meningkatkan Kemampuan Pemecahan Masalah Soal Cerita Pecahan pada Siswa Kelas VII SMP Negeri 13 Palu. Jurnal Elektronik Pendidikan Matematika Tadakulo, 01, 148. 
Widza Nhurul Desyawati

Johnson, E.B. (2007). Contextual Teaching and Learning: Menjadikan Kegiatan Belajar Mengajar Mengasyikan dan Bermakna. Terjemahan oleh Ibnu Setiawan. Bandung: Mizan Learning Center.

Kariadinata, R. (2012). Dasar-dasar Statistik Pendidikan. Bandung: CV. Pustaka Setia. Majid, A. (2014). Strategi Pembelajaran. Bandung: PT. Remaja Rosdakarya.

Polya, G. (1985). How to Solve it. United States of America: Princeton University Press. Sugiyono. (2015). Metode Penelitian Kuantitatif Kualitatif dan R\& D. Bandung: Alfabeta.

Zubaidah, Siti. (2015). Asesmen Berpikir Kritis Terintegrasi Tes Essay, Jurnal Symposium On Biology Education. 